\title{
DESTINATION CRISIS MANAGEMENT EDUCATIONAL PROGRAMS - BACKGROUND FOR BETTER PERFORMANCES
}

\author{
Dora Smolčić Jurdana \\ Romina Agbaba
}

https://doi.org//10.20867/tosee.06.46

\begin{abstract}
Purpose - Paper points out the importance of introducing and attending various educational programs, courses and workshops that are crucial in times of crisis. Knowledge resources need to be more integrated within management organizations, to ensure efficiency and effectiveness in overcoming challenging conditions. Managers must learn and devise new ways of managing in times of crisis.

Methodology - Secondary data sources, relevant studies closely related to this area of research, indexed in the databases WoS, Scopus, Hrčak, and others where used. Countries Australia, Croatia and China were selected and analyzed, with the intention of indicating the degree of representation of educational programs in the field of crisis management, or whether they exist in university education, business activities, are they publicly available and is their theme exclusively based on the still present COVID-19 pandemic?

Findings - Based on the research of educational programs in the field of crisis management in three selected countries (China, Australia, Croatia) from three different continents, it was noticed regardless of the difference in their size and education systems, that there are no significant deviations in the modalities of educational programs in crisis management.

Contribution - The contribution is manifested in the representation and the literature review of contribution of educational programs in the field of crisis management. Given the occurrence of crisis situations in tourism, which are increasingly common and come from different sources, the need to strengthen educational programs in this area has undoubtedly been identified.

Keywords: tourist destination, crisis, crisis management, education.
\end{abstract}

\section{INTRODUCTION}

The tourism industry is highly vulnerable to crises, as tourism is affected by many external factors, including political instability, economic conditions, the environment and weather. Crises due to their nature, size and scale threaten the sustainability of tourism businesses and destinations, creating a high level of uncertainty. Given the above, the crisis phases will also differ. Understanding crises and developing their management skills has never been more important. Consequently, destination managers need to be able to anticipate such events and respond skillfully and strategically, in which professional expertise and knowledge are essential. In achieving that goal, investing in their education through an ongoing learning process is crucial. Today's business environment is characterized by great uncertainty and risk, which is why many organizations are not adequately prepared, which imposes the need for additional training in terms of crisis situations. Through effective management, the goal is to avoid or reduce 
ToSEE - Tourism in Southern and Eastern Europe, Vol. 6, pp. 695-707, 2021.

D. Smolčić Jurdana, R. Agbaba: DESTINATION CRISIS MANAGEMENT EDUCATIONAL ...

the negative effects of crises. In this context, continuous education has become an imperative for survival, adaptability, competitiveness and long-term sustainability.

The purpose of this paper is to explore educational programs of different levels and types. Due to the limited scope of the research, three countries on three different continents were selected, with the aim of noticing mutual similarities and differences. The content analysis of secondary sources of literature pointed out the diversity and complexity of crises, the importance of learning about crisis management and the changes that result from it.

\section{DESTINATION CRISIS MANAGEMENT}

With the aim of preventing destructive events and reducing their significant consequences for a significant number of competent people and legitimate institutions, the solution is crisis management, as a scientific-teaching discipline and research area. Given the lack of appropriate knowledge conducive to crisis situations, education is becoming one of the important forms of management and development. The results of previous research conducted in this area represent useful examples of crisis management in the destination (Ivanović 2014).

Management aims to establish an effective organization, which will respond to changing goals and circumstances. On the other hand, a crisis is a situation whose outcomes cannot be fully predicted or planned; for example, a mission is carried out expecting one thing, while something completely different happens. It includes a sense of responsibility for others, an intense effect, and moral responsibility. In order to achieve the goals and ensure the survival of the destination, it is necessary to manage its development, which implies constant strategic planning and reflection. It is necessary to combine resources and create a specific tourist product that will be recognizable and competitive in the tourist market. The concept of destination management consists of a series of activities, such as planning, organizing, controlling, leading and finding human resources. The role of the destination, and at the same time crisis manager, is manifested in connecting all tourism stakeholders and resources in the area of the tourist destination, in order to achieve individual and global goals.

Therefore, constant education and training of staff at all levels is necessary (Bosnić, Stanišić and Tubić 2014). Crisis management identifies, diagnoses and analyzes the situation and takes measures to overcome the crisis (Ivanović 2014). The function of educational managers includes: strategic development, job planning and forecasting, motivation, organization, computerization and information management (Arenova, Bayarystanova and Nurmuhametova 2014). As a model, crisis management includes: life cycle approach, strategic management, action-oriented management and integrated approach. In the initial phase of crisis management, guidelines are proposed, such as the inclusion of crisis planning and the formation of a working group and partnership. Then more concrete details are given on each phase of management and implementation of appropriate strategies. An integrated approach implies proactive (mitigation, preparedness and warning) and reactive strategies (impact assessment) applicable during all crisis phases (Jiang and Ritchie 2019). 
ToSEE - Tourism in Southern and Eastern Europe, Vol. 6, pp. 695-707, 2021.

D. Smolčić Jurdana, R. Agbaba: DESTINATION CRISIS MANAGEMENT EDUCATIONAL ...

Crisis management, in a broader sense, includes activities from preventive action before the crisis, through crisis management in a narrower sense, to learning new ways of thinking and acting during a crisis. It is necessary to pay attention to the characteristics of the crisis period and use the instruments of effective crisis management accordingly. The impact of the crisis on management is manifested through: crisis signals that are ignored, managers' reactions in line with past experience, tolerance of uncertainty is reduced and the time perspective on current and immediate problems is narrowed. Management's reactions to crises are different and can be as follows (Funda and Majić 2011):

- Crisis rejection - management refuses to see signs of crisis; it exists but is hidden

- Explaining the crisis - the crisis is visible, but management finds explanations for believing that the crisis is temporary and timely action is lacking

- Deepening the crisis - action is taken, but the required degree of change is underestimated

- Organization collapse - the best people leave, which reduces the ability to make decisions

In order to resolve the crisis, it is necessary to act quickly and decisively, communicate openly and have strong leadership. It is necessary to learn something new from each crisis and gain some experience that will be applicable in the future, in a way that reduces or minimizes the negative consequences of the crisis. The following strategies can be used to respond to the crisis: downsizing, rebuilding, strengthening, efficiency, change management, new product or market, and marketing improvement (Funda and Majić 2011).

Learning from a crisis involves analyzing a crisis event, with the aim of obtaining the most important lessons, given how the main actors acted, and then they need to be turned into lessons learned. If the commitment of the top management is not behind everything, with a motivated team, familiar with the methodology and accompanying dangers, problems in terms of time and motivation may arise. The high degree of uncertainty, ambivalence and ambiguity, characteristic of crisis situations, makes it difficult to learn lessons from a crisis event (Kešetović and Toth 2012). Since crises can also be viewed as 'emotional' events, effective management requires a high degree of emotional intelligence, such as awareness of oneself, others and the environment (Alpaslan, Mitroff and Shrivastava 2013). Furthermore, a crisis experience is usually accompanied by tension, feelings of loss, incompetence, confusion, and despair, which on the one hand can lead to conflict and resistance to change, while on the other hand, it can trigger positive change. Given the above, effective crisis management is important for the longterm benefit of the destination. This process involves constant assessment and learning from the present, along with planning for that future, desired state (Wang 2008).

Managers as leaders must be focused on priorities, because the environment reacts in unpredictable ways, which means that new challenges and opportunities can always emerge. Preparing for the unexpected encompasses not only the technical aspects of the tasks, but also those cognitive and emotional requirements. Although managers may not be fully prepared for all crisis situations, they themselves develop a mindset that helps 
ToSEE - Tourism in Southern and Eastern Europe, Vol. 6, pp. 695-707, 2021.

D. Smolčić Jurdana, R. Agbaba: DESTINATION CRISIS MANAGEMENT EDUCATIONAL ...

them accept that they are unable to keep everything under control. In the recovery cycle, leaders identify lessons learned, build resilience through conversation, experience renewal, and express compassion for others (Allen, Kayes and Self 2012). Crisis management on the one hand includes management with forecasting, planning, providing guidance and assistance in crisis control, and on the other hand, the crisis is unique, specific and, a priori, why it is complex to manage. Every crisis manager should have the following competencies: self-confidence, willingness to take responsibility, motivation and articulation of visions and missions, resilience, communication, analytical and social skills, determination, flexibility, delegation, operational planning, team building and networking (Lalonde and Roux-Dufort 2013). Likewise, crisis management is defined as a comprehensive effort that organizations make in an attempt to primarily understand and prevent a crisis and manage it effectively (Hosie and Pforr 2008).

Destination crisis management also depends on the behavior of the manager who encourages members to actively engage and acquire knowledge and formulate strategies in response to the crisis. As the business environment changes and becomes more complex, it is especially important that managers develop a set of skills that will help them in prevention and effective response to crises, but also in relation to other strategic issues (Hayes and Perry 2008). Crisis management educational programs should have a strategic approach. Crisis managers must be able to understand the problems created by the situation they may face and in order to be able to make an effective decision, they need to have certain knowledge and experience. Once decisions have been made, the crisis manager must be able to implement strategies that can mitigate the problem and be flexible enough to adapt to rapidly evolving changes (Chermack, Dooley and Moats 2008).

\section{IMPORTANCE OF EDUCATIONAL PROGRAMS}

The educational system must provide professional knowledge and key competencies, skills and abilities facilitating the integration on labor markets and in social life (Ghic 2011). In the context of crisis management, knowledge from past experiences is a prerequisite for better preparedness and a more effective response to crises in the future. This is particularly reflected in tourist regions, which are characterized by a high probability of a crisis. The concepts of organizational learning and knowledge management have been applied in the study of tourism crises. As this process is time consuming, destinations need to assess all resources in detail and analyze feedback on the effectiveness of their strategies (Jiang and Ritchie 2019). It is crucial to conduct regular staff training and exercises, so that teams are prepared for upcoming situations. Crisis simulation helps with emergency protocols, but also identifies those areas that need to be improved. An example of this is the regular 'stress' testing of banks after the 2008 recession, which has become common practice. As a result, banks are now more resilient and better prepared for future economic crises (Jiang and Ritchie 2019).

Frequent changes in today's environment impose the need for constant education, beacuse it plays a key role in crisis management (Jones and Ratten 2020). It is necessary 
ToSEE - Tourism in Southern and Eastern Europe, Vol. 6, pp. 695-707, 2021.

D. Smolčić Jurdana, R. Agbaba: DESTINATION CRISIS MANAGEMENT EDUCATIONAL ...

to devise new strategies that will be applicable during and after the crisis and to integrate knowledge resources into the system of internal organization, with the aim of overcoming challenging conditions (Saide and Sheng 2020). Educational programs are conducted for the purpose of transferring knowledge, information, skills, attitudes, behaviors and other values. The application of knowledge as the main educational aspect helps to achieve business goals, where the process of transfer from source to recipient is possible primarily through education. Given the existing COVID-19 pandemic, online activities that take place via video and webinars, across different platforms are becoming increasingly important (Saide and Sheng 2020).

Making quick decisions can be a challenge for managers, as they are facing uncertainty, risks and a lot of pressure. In order to encourage interaction with employees, and at the same time ensure the exchange of information, it is necessary to hold regular meetings by taking advantage of modern technologies (Constantiou et al. 2020). The positive effect of the crisis is reflected in the ability to learn and adapt, but it is not easy to determine what went wrong and what needs to be changed, in order to prevent the recurrence of similar events. From the same crisis experience, it is possible to get different, and sometimes completely opposite results. After each crisis, managers and the work team should meet and conduct a comprehensive analysis of both the right and good actions, as well as the mistakes and omissions that have been made, which includes the following elements:

- warning signs that have been taken into account and those that have been ignored

- the emergence of a crisis in time

- preparation of plans and teams

- formation of a crisis team.

Education is significant for management and development, as the lack of appropriate knowledge is conducive to crisis situations. Preventive management considers possible options for crisis situations in order to respond in a timely manner and prevent them (Ivanović 2014). Because crisis situations often involve novelty and complexity of the task, managers need to be further educated. In a crisis situation, the need for learning is more pronounced and the process itself is more demanding. Crisis situations in this regard provide opportunities for managers to explore situations where circumstances do not fit expectations and to develop the skills used to cope with elevated levels of anxiety (Allen, Kayes and Self 2012). As crises are dynamic and evolving processes, with elements of surprise, learning from previous experiences is not enough for an effective future response to a crisis. Crisis-induced learning encompasses actions taken by destination stakeholders, with the goal of a new understanding that leads to future behavior. What all crises have in common is that these are situations in which decisionmakers perceive time pressure, uncertainty and threat to the realization of set goals. As a lifelong activity, it is the basis for a continuous increase in knowledge within and between individuals (Deverell 2012).

Anticipating and preparing to deal with crises and their consequences, caused by natural or human factors, is one of the tourism challenges. Tourism is particularly vulnerable to such negative events that pose a constant threat to it. It is human resources and their development that are a key component of crisis preparation and management. Educating 
ToSEE - Tourism in Southern and Eastern Europe, Vol. 6, pp. 695-707, 2021.

D. Smolčić Jurdana, R. Agbaba: DESTINATION CRISIS MANAGEMENT EDUCATIONAL ...

them to deal with crisis management is a way to reduce the vulnerability of tourist destinations to crises, as they can occur if managers are not equipped or do not have sufficient resources for timely and decisive action. Thus, educational programs, such as training, play an important role in all this, as a 'planned process focused on changing knowledge, skills or attitudes to achieve established and measurable results' (Hosie and Pforr 2008). Through learning, a destination can improve its crisis management skills and build resilience. Given the crisis creates a sense of urgency, decisions need to be made as soon as possible, which sometimes entails the risk of superficial learning, without attempting to analyze the underlying problem.

Learning from the crisis is necessary to avoid future adverse events, which is also the purpose of crisis management (Hamnevoll, Sydnes, A.K. and Sydnes, M. 2021). In most cases, managers and the team are not ready to manage the crisis, so inadequate crisis management can result in negative, long-term consequences on profitability, destination reputation, market position and human resource management. Crisis management as one of the tasks of management requires special knowledge, skills and abilities, with managers at the helm, who must empathize with others and in turn act in their interest (Hayes and Perry 2008).

Preparing crisis managers for effective decision makers in crises requires comprehensive and coordinated planning and education. Given that they operate in complex environments, it is necessary to implement methods that will minimize the risk of crisis, and on the other hand to develop its management. Despite the fact that the crisis will sometimes not be possible to prevent, it is necessary to do everything possible to reduce the likelihood of their occurrence, and later the consequences (Chermack, Dooley and Moats 2008).

\section{CRISIS MANAGEMENT EDUCATIONAL PROGRAMS - EXAMPLES FROM DIFFERENT COUNTRIES}

Crises require a radical transformation of the way people communicate and act in the workplace, which also affects many aspects of everyday life. With the still-present COVID-19 pandemic, many organizations are forced to embrace new ways of working remotely, using digital communication systems and completely rethinking their business models, to adapt to the emerging environment. The 'Zoom' and 'Microsoft Teams' platforms are largely used for meetings, video conferences, various webinars and educational programs. However, the implementation and coverage of such programs requires the monitoring and support of trained educators, which is why both parties, teachers and students, need to be better prepared (Barbosa and Montoya 2020).

Exercises for emergency situations are planned activities that imitate an extraordinary event, with the aim of educating and training staff, checking protection and rescue plans, procedures, techniques and equipment, and achieving effective functioning and coordinated action in real crises. Their main task is to assess the capabilities and readiness of individual destination managers and teams and to identify those areas where improvements or changes are urgently needed. Exercises can also be used as a tool to 
ToSEE - Tourism in Southern and Eastern Europe, Vol. 6, pp. 695-707, 2021.

D. Smolčić Jurdana, R. Agbaba: DESTINATION CRISIS MANAGEMENT EDUCATIONAL ...

identify gaps in legislation and/or rules made by governments, local governments or other stakeholders. Effective preparation for action in crisis situations is not possible without detailed planned and designed exercises, which also test plans prepared for crisis situations. The basis for this is previously acquired knowledge and skills that are acquired through education and seminar activities (Lebeda and Mihalić 2011). Experiential learning involves memorizing, organizing, recording, and retrieving past actions. It is characteristic for professions that mostly routinely deal with certain types of crises, through standardized procedures for recording and reviewing past experiences. One of its forms is the acquisition of competencies, as learning is often conceptualized as the ability or skill to solve increasingly complex tasks. Skill refers to the capacity to implement intentions into successful outcomes with adequate resources, with application of practical knowledge on how to achieve something. Closely related to the development of competencies is the development of material resources that can facilitate the solution of the task, such as improving tools or infrastructure (Kešetović and Toth 2012). In order to protect the destination from future crises, purposeful learning is needed, in which changes are made in the system that caused the crisis. It is suggested to perform exercises in which members of the crisis team try to act consciously from different perspectives, which allows them to recognize the way they understand a particular problem. Training potentially inhibits the ability to look at solutions outside the learned thinking frame (Veil 2011)

Numerous simulations and crisis management exercises allow participants to learn about the elements of crisis decision making and communication through practical examples. Simulations help create community and build trust among team members, which is crucial in real crises. Examples include involving trainees in projects such as crisisaffected areas (New Orleans after Hurricane Katrina) or volunteering in the organization's crisis engagements (homeless shelters, domestic violence prevention programs, etc.).

This presents unique learning opportunities for understanding crises. In addition, management teachers need to integrate crisis analysis into their existing courses and develop stand-alone crisis management courses. Crisis management education needs to be socially and historically contextualised, going beyond abstract and cognitive understanding, and embodying the experiential (Alpaslan, Mitroff and Shrivastava 2013).

To meet the growing need for crisis management information and education, many business schools and institutions are introducing crisis management courses for students and managers - including, for example, the Adam Smith Business School (University of Glasgow), Darden School of Business (University of Virginia), DeGroote School of Business (McMaster University), European School of Management and Technology (ESMT), Jones Graduate School of Business (Rice University), Kellogg School of Management (Northwestern University), Schulich School of Business (York University), Stanford Graduate School of Business (Stanford University), and countless others. Offers include electives, company-specific programs, as well as a series of open courses for enrollment on this topic (Lei, Pratten and Waller 2014). 
ToSEE - Tourism in Southern and Eastern Europe, Vol. 6, pp. 695-707, 2021.

D. Smolčić Jurdana, R. Agbaba: DESTINATION CRISIS MANAGEMENT EDUCATIONAL ...

Simulated crisis scenarios are often cited as effective tools for organizational and individual learning, whose participants need to work together to find appropriate solutions. The goal is to reproduce reality, so that participants can experience the elements of crisis management, which they will actually experience when a real crisis occurs. This can be used to train and test the effectiveness of the training program, the plan, as well as the ability of staff to execute the plan (Borodzicz and Van Haperen 2002).

Scenario planning is the process of setting up informed, plausible, and imagined alternative environments related to the future, for the purpose of changing existing thinking, learning, and improved performance. As a training method, it represents an interaction in a similar context and environment in which the problem would normally be located (Chermack, Dooley and Moats 2008).

Crisis management educational programs in these countries were analyzed according to university study programs, webinars, workshops and courses. The analysis showed that there are no significant differences in educational programs and that in recent times webinars are mostly related to the COVID-19 pandemic. As part of crisis management, there is Daxue Consulting in China, a research and strategy agency, established on the Beijing Daxue campus in 2009 (Daxue Consulting, 2020). Also, numerous webinars on the topic of crisis management were held:

- Reopening of schools in China

- Crisis management during COVID-19 and impact on EU SMES

- The outlook for foreign-invested SMES in China

- China: from crisis to recovery

- Lessons from the current governance and COVID-19 crisis.

The most prominent is Nanjing University, within which the Center for Risk, Disaster \& Crisis Research (CRDCR) was established in 2005, as a leader in risk and crisis management research in China. The goal is to develop a new discipline that focuses on non-routine risk management in society. Internationally, the Center collaborates with leading research institutions, such as the Center for Disaster Management at the University of Pittsburgh and the Crisis Management Program at Harvard University. At the same Faculty, there are also study programs in english: 'China's practice in crisis and public management', where students are provided with theoretical and practical knowledge about crisis management (Nanjing University 2020). The curriculum emphasizes improving students' understanding of the crisis and public governance practices in China, including institutional frameworks, regimes, and policies. Upon completion of all required courses, graduate students will be equipped with the professional knowledge, research skills, and interdisciplinarity to respond to the challenges of today's global risk society (Nanjing University n.d.).

The University of Queensland in Australia, offers the opportunity to take the 'International Crisis Management' course for exchange students. It introduces them to the world of disaster management, with a special emphasis on the development context and international comparison. The aim is to examine whether destinations can reduce vulnerability to disasters and strengthen pre-crisis preparedness, as well as to meet the extraordinary challenges facing institutions and managers in charge of responding to the 
ToSEE - Tourism in Southern and Eastern Europe, Vol. 6, pp. 695-707, 2021.

D. Smolčić Jurdana, R. Agbaba: DESTINATION CRISIS MANAGEMENT EDUCATIONAL ...

crisis. By analyzing the literature, from public policy, governance, development, geography, anthropology, and a series of current case studies (earthquakes in Haiti and Pakistan, the Asian tsunami, floods in Bangladesh, landslides in Uganda), students will gain insight into disaster management (The University of Queensland 2021a).

Furthermore, the Faculty of Health \& Behavioral Sciences, as part of the course 'Counseling for crisis and violence' in postgraduate studies, deals with understanding the theoretical and ethical foundations of work on crises and violence and provides a platform for developing interventions that enable service users to develop resilience and independence. In addition, it discusses how people feel, think, act, and behave, when faced with the challenges of a critical event. The introductory part of the course includes the presentation of definitions of violence and crisis, while later it deals with knowledge and approaches to practice in working with people who face these life events (The University of Queensland 2021b). At the same Faculty, the course 'Issues and crisis management' is also taught. Because problem identification and management, together with crisis planning and response, are key to building and maintaining stakeholder relationships, students in this course identify, analyze, and develop strategies for organizational, industrial, and environmental challenges, using a variety of management theories, models, and methods. Applied techniques include environmental scanning, problem mapping, and crisis communication planning (The University of Queensland 2021c).

Charles Sturt University has the opportunity to attend the online courses 'Master of Leadership \& Management' and 'Master of Terrorism and Security Studies', which focus on developing skills to improve leadership skills. Analytical skills are crucial in identifying and managing competitive risks and priorities in the administrative and operational environment.

The University of Newcastle has two master's programs, which are optionally conducted in onsite and online terms: 'Master of disaster resilience and Sustainable Development' and 'Leadership and Management in education' and one postgraduate program 'Disaster risk reduction'. These programs aim to train for the principles of resilience and sustainable development and their systematic application, in order to avoid crises, act in extreme events and better position for the future. With a degree in 'Disaster risk reduction', students will be able to conduct crisis risk assessments and develop management and mitigation strategies. 'Emergency and Disaster Management' is present at Cquniversity Australia in Melbourne and at the Faculty of Engineering, Health, Science and the Environment in Darwin, and acquires skills and knowledge in working as an expert in emergency and crisis management. The 'Complex systems' master program includes modeling, analysis and design of resilient technological, socioeconomic and socio-ecological systems, as well as the development of crisis forecasting and management strategies. A multidisciplinary approach to observing natural hazards and the ways in which society can build resilience to them are available in postgraduate study at the University of New England, as part of the course 'Planning and management of natural hazards'. Events are also held in Australia, such as: Crisis Mangement Training, Manager Management 1 Day Training in Sydney, Knowledge Management 1 Day Training in Sydney, Elements Of Risk Management 1 Day Training in Sydney, Crisis Communications and Reputation Management, Crisis, Resilience \& Emergency 
ToSEE - Tourism in Southern and Eastern Europe, Vol. 6, pp. 695-707, 2021.

D. Smolčić Jurdana, R. Agbaba: DESTINATION CRISIS MANAGEMENT EDUCATIONAL ...

Preparedness 2020, which as a kind of programs provide the opportunity to interact with educators and develop the skills needed for certain crisis events.

Also, participants will be able to recognize warning signs earlier, to completely avoid negative situations or, if the situation occurs, to better manage the crisis, then apply effective crisis management tools and techniques, develop crisis management plans and identify measures to improve crisis management destination capabilities. During this and next year, conferences have been announced in Perth and Sydney: International Conference on Business, Management and Governance (ICBMG), International Conference on Tourism Crisis Management (ICTCM) and International Conference on Crisis Management in Tourist Destinations (ICCMTD), all exclusively related with crisis management, which further contributes to the relevance of this research area.

The importance of crisis management is also evident in Croatia, where it is important to highlight the 'Days of Crisis Management' which have been held in Velika Gorica since 2011. Thematic areas cover crisis management, homeland security and security of local communities, crisis communication, systems, devices, means and equipment for crisis management and similar (Veleučilište Velika Gorica n.d.). There is also a Specialist Graduate Professional Study of Crisis Management in the eponymous place, where students acquire knowledge and competencies for independent problem solving, crisis management and security and protection management processes and systems in the public and private sector. Postgraduate specialist interdisciplinary study of crisis management can be enrolled at the University of Zagreb and 'Crisis Management' as an elective course at the University of Slavonski Brod, as part of the specialist graduate professional study 'Management' (Sveučilište u Zagrebu, n.d.). Also, there is the Croatian Crisis Management Association, founded in 2003, which aims to encourage, promote and develop a crisis management system, protection and rescue, management principles and disaster relief (Croatian Crisis Management Association, 2021). In order to better understand crises and their causes, crisis management and learning, numerous seminars, courses and trainings were held, such as: Crisis Management, Crisis Management and Crisis Communication, How to organize and manage your own crisis management?, Crisis Management Expert, Crisis management in corona time in the pharmaceutical industry, etc.

From all the above, it can be concluded that different educational programs contribute to better preparedness for crisis situations, as they illustrate the same through possible situations and examples of good practice.

\section{CONCLUSION}

Regardless of the level of tourism development of the destination and the geographical area in which it is located, crisis management in tourism, at all levels of decision-making is becoming increasingly complex. In addition, it is important to emphasize that in conditions of very dynamic and increasingly difficult to predict global changes, the survival, growth and development of a tourist destination requires continuous strategic investments and activities. Once the crisis is overcome, every learning opportunity should be used. There are few who see the crisis as an opportunity, not just a threat, and 
ToSEE - Tourism in Southern and Eastern Europe, Vol. 6, pp. 695-707, 2021.

D. Smolčić Jurdana, R. Agbaba: DESTINATION CRISIS MANAGEMENT EDUCATIONAL ...

who learn from the crisis how to act, in order to prevent or mitigate their negative consequences in the future and plan future activities. A crisis situation can release additional strength and strengthen the readiness for change, initiate product and process innovations, leadership style, ways of cooperating and stimulate the creative potential of employees. As specific knowledge and skills are required for this research area, it is unquestionable that work on crisis prevention is important and useful, both for individuals and for society. In this sense, it is necessary to constantly invest in education and the acquisition of knowledge in various disciplines.

Educational programs aim to develop conceptual skills that will help in crisis prevention and management. Exercises in brainstorming, improvisation and problem-solving creativity can improve abilities when dealing with crises. The crisis management team must meet regularly, learn from crises occurring in other destinations, fully analyze all significant incidents, and undergo training that uses realistic simulations.

In addition, at least once a year, it is extremely important to test the plan and behavior in crisis situations in advance. To manage effectively, crisis managers must first be able to recognize early warning signals, long before the crisis itself occurs. Ultimately, managers and employees must be continuously educated and successively assessed on crisis management, practicing and using feedback to restructure and improve existing crisis management systems. Learning should be present at every stage of the crisis management process, so that managers can identify, prevent, plan and deal with the crisis in a timely manner.

The article is intended for educational institutions, tourist destination management and public administrations. Recommendations for future research are directed towards the need to investigate the connection between available crisis management programs in tourism, adopted and implemented tourism policy measures and finally achieved results.

\section{REFERENCES}

Allen, C.N., Kayes, D.C. and Self, N. (2012), "Integrating Learning, Leadership, and Crisis in Management Education: Lessons From Army Officers in Iraq and Afghanistan", Journal of Management Education, Vol. 37, No. 2, pp. 180-202. https://doi.org/10.1177/1052562912456168

Alpaslan, C.M., Mitroff, I. and Shrivastava, P. (2013), "Imagining an Education in Crisis Management", Journal of Management Education, Vol. 37, No. 1, pp. 6-20. https://doi.org/10.1177/1052562912455418

Arenova, A., Bayarystanova, E. and Nurmuhametova, R. (2014), "Education System Management And Professional Competence Of Managers", Procedia - Social and Behavioral Sciences, Vol. 140, pp. 427-431. https://doi.org/10.1016/j.sbspro.2014.04.448

Barbosa, A. and Montoya, S. (2020), The Importance of Monitoring and Improving ICT Use in Education PostConfinement, viewed 10 March 2021, http://uis.unesco.org/en/blog/importance-monitoring-andimproving-ict-use-education-post-confinement

Borodzicz, E. and Van Haperen, K. (2002), "Individual and Group Learning in Crisis Simulations", Journal of Contingencies and Crisis Management, Vol. 10, No. 1, pp. 139-147. https://doi.org/10.1111/14685973.00190

Bosnić, I., Stanišić, J. and Tubić, D. (2014), "Role of destination management in strengthening the competitiveness of Croatian tourism", Ekonomski vjesnik, Vol. 27, No. 1, str. 153-170. https://hrcak.srce.hr/127788 
ToSEE - Tourism in Southern and Eastern Europe, Vol. 6, pp. 695-707, 2021.

D. Smolčić Jurdana, R. Agbaba: DESTINATION CRISIS MANAGEMENT EDUCATIONAL ...

Chermack, T.J., Dooley, L.M. and Moats, J.B. (2008), "Using Scenarios to Develop Crisis Managers: Applications of Scenario Planning and Scenario-Based Training", Advances in Developing Human Resources, Vol. 10, No. 3, pp. 397-424. https://doi.org/10.1177/1523422308316456

Constantiou, I. et al. (2020), "Impact of COVID-19 pandemic on information management research and practice: Transforming education, work and life", International Journal of Information Management, Vol. 55. https://doi.org/10.1016/j.ijinfomgt.2020.102211

Daxue Consulting (2020), Crisis management in China, viewed 18 March 2021, https://daxueconsulting.com/crisis-management-in-china/

Deverell, E. (2012), "Is best practice always the best? Learning to become better crisis managers", Journal of Critical Incident Analysis, Vol. 3, No. 1, pp. 26-40. http://jcia.aciajj.org/files/2012/12/Deverell-2Final.pdf

Funda, D. and Majić, T. (2011), Upravljanje krizom, u IV. Međunarodna konferencija "DANI KRIZNOG UPRAVLJANJA", Velika Gorica, Hrvatska, pp. 47-60. https://dku.hr/wpcontent/uploads/2016/09/zbornik2011.pdf

Ghic, G. (2011), "Solutions for alternative education in crisis period", Procedia Social and Behavioral Sciences, Vol. 15, pp. 2284-2287. https://doi.org/10.1016/j.sbspro.2011.04.094

Hamnevoll, H., Sydnes, A. K. and Sydnes, M. (2021), "Learning from crisis: The 2015 and 2017 avalanches in Longyearbyen", Safety Science, Vol. 134. https://doi.org/10.1016/j.ssci.2020.105045

Hayes James, E. and Perry Wooten, L. (2008), "Linking Crisis Management and Leadership Competencies: The Role of Human Resource Development", Advances in Developing Human Resources, Vol. 10, No. 3, pp. 352-379. https://doi.org/10.1177/1523422308316450

Hosie, P.J. and Pforr, C. (2008), "Crisis Management in Tourism", Journal of Travel \& Tourism Marketing, Vol. 23, No. 2-4, pp. 249-264. https://doi.org/10.1300/J073v23n02_19

Hrvatska udruga kriznog menadžmenta (2021), O nama, viewed date: 18.03.2021., http://hukm.hr/hr/o-nama/ Institute for International Students, Nanjing University (2020), China's Practice in Crisis and Public Management, viewed 18 March 2021, https://hwxy.nju.edu.cn/_t486/80/48/c6142a491592/page.htm

Ivanović, V. (2014), "Pojam krize: konceptualni i metodologijski aspekti”, Međunarodne studije, Vol. 14, No. 2, str. 10-28. https://hrcak.srce.hr/143305

Jiang, Y. and Ritchie, B.W. (2019), A review of research on tourism risk, crisis and disaster management: Launching the annals of tourism research curated collection on tourism risk, crisis and disaster management. Annals of Tourism Research, Vol. 79. https://doi.org/10.1016/j.annals.2019.102812

Jones, P. and Ratten, V. (2020), "Entrepreneurship and management education: Exploring trends and gaps", The International Journal of Management Education, Vol. 19., No. 1. https://doi.org/10.1016/j.ijme.2020.100431

Kešetović, Ž. and Toth, I. (2012), “Problemi kriznog menadžmenta”, u Kriza i učenje, Veleučilište Velika Gorica, Velika Gorica, pp. 173-195. https://bib.irb.hr/datoteka/587578.Toth-Krizni_menadzmentsmall.pdf

Lalonde, C. and Roux-Dufort, C. (2013), "Challenges in Teaching Crisis Management: Connecting Theories, Skills, and Reflexivity", Journal of Management Education, Vol. 37, No. 1, pp. 21-50. https://doi.org/10.1177/1052562912456144

Lebeda, N. and Mihalić, M. (2011), "Evaluacija vježbi krizne situacije”, u IV. Međunarodna konferencija “DANI KRIZNOG UPRAVLJANJA”, Velika Gorica, Hrvatska, pp. 147-161. https://dku.hr/wpcontent/uploads/2016/09/zbornik2011.pdf

Lei, Z., Pratten, R. and Waller, M.J. (2014), "Focusing on Teams in Crisis Management Education: An Integration and Simulation-Based Approach", Academy of Management Learning \& Education, Vol. 13, No. 2, pp. 208-221. https://doi.org/10.5465/amle.2012.0337

Nanjing University, n.d., Center for Risk, Disaster and Crisis Research, viewed 18 March 2021, https://www.nju.edu.cn/EN/8c/43/c7549a166979/page.psp

Saide, S. and Sheng, M.L. (2020), "Knowledge exploration-exploitation and information technology: crisis management of teaching-learning scenario in the COVID-19 outbreak", Technology analysis and Strategic Management. https://doi.org/10.1080/09537325.2020.1854714

Sveučilište u Zagrebu, n.d., Poslijediplomski specijalistički interdisciplinarni studij Upravljanja krizama, viewed 18 March 2021, http://www.unizg.hr/istrazivanje/specijalisticki-studiji/sveucilisniinterdisciplinarni-specijalisticki-studiji/upravljanje-krizama/

The University of Queensland (2021a), International Crisis Management (POLS7306), viewed 18 March 2021, https://my.uq.edu.au/programs-courses/course.html?course_code=POLS7306

The University of Queensland (2021b), Counselling for Crisis and Violence (COUN7019), viewed 18 March 2021, https://my.uq.edu.au/programs-courses/course.html?course_code=COUN7019 
ToSEE - Tourism in Southern and Eastern Europe, Vol. 6, pp. 695-707, 2021.

D. Smolčić Jurdana, R. Agbaba: DESTINATION CRISIS MANAGEMENT EDUCATIONAL ...

The University of Queensland (2021c), Issues and Crisis Management (COMU7302), viewed 18 March 2021, https://my.uq.edu.au/programs-courses/course.html?course_code=COMU7302

Veil, S.R. (2011), "Mindful Learning in Crisis Management", Journal of Business Communication, Vol. 48 No. 2, pp. 116-147. https://doi.org/10.1177/0021943610382294

Veleučilište Velika Gorica, n.d., Krizni menadžment, viewed 18 March 2021, https://vvg.hr/ostudijima/specijalisticki-studij/krizni-menadzment/

Wang, J. (2008). "Developing Organizational Learning Capacity in Crisis Management”, Advances in Developing Human Resources, Vol. 10, No. 3, pp. 425-445. https://doi.org/10.1177/1523422308316464

Dora Smolčić Jurdana, PhD, Tenured professor

University or Rijeka, Faculty of Tourism and Hospitality Management

Department for tourism

Primorska 46, 51410 Opatija, Croatia

+385- 51-294-186

doras@fthm.hr

Romina Agbaba, Assistant

University or Rijeka, Faculty of Tourism and Hospitality Management

Department for tourism

Primorska 46, 51410 Opatija, Croatia

+385-51-294-886

romina.agbaba@fthm.hr 